\title{
Narratives of 19th century drought in southern Africa in different historical source types
}

\author{
David J. Nash a,b,* \\ Jørgen Klein ${ }^{\mathrm{c}}$ \\ Georgina $\mathrm{H}$. Endfield ${ }^{d}$ \\ Kathleen Pribyl e,f \\ George C.D. Adamson ${ }^{g}$ \\ Stefan W. Grab b
}

\section{Affiliations:}

a Centre for Aquatic Environments, School of Environment and Technology, University of Brighton, Brighton BN2 4GJ, UK

b School of Geography, Archaeology and Environmental Studies, University of the Witwatersrand, Private Bag 3, Wits 2050, South Africa

c Department of Social Sciences, Inland Norway University of Applied Sciences, 2418 Elverum, Norway

d Department of History, University of Liverpool, 8-14 Abercromby Square, Liverpool L69 7WZ, UK

e Climatic Research Unit, School of Environmental Sciences, University of East Anglia, Norwich NR4 7TJ, UK

f Oeschger Centre for Climate Change Research, University of Bern, Hochschulstrasse 4, 3012 Bern, Switzerland

g Department of Geography, King's College London, Bush House (North East Wing), 30 Aldwych, London WC2B 4BG, UK

\section{Corresponding author:}

* D.J. Nash, School of Environment and Technology, University of Brighton, Lewes Road, Brighton BN2 4GJ, UK

E-mail: d.j.nash@brighton.ac.uk

ORCID: 0000-0002-7641-5857 


\section{Abstract}

Single- to multiple-year drought episodes posed significant challenges for agrarian communities across southern Africa during the 19th century, and hence are widely recorded in a variety of historical documents. However, the ways in which droughts are articulated, and the focus of individual accounts, varies considerably between different authors and historical source types. This study draws on a range of documentary source types - specifically newspapers, letters, reports and diaries - to explore the varied narratives associated with three protracted droughts (those of 1861-63, 1876-79 and 1895-97) that affected large areas of the subcontinent. The analysis spans four case study areas - present day KwaZulu-Natal (South Africa), Lesotho, Malawi, and the southern Kalahari (Botswana and South Africa) - which were investigated as part of different interdisciplinary projects. We explore issues common to all case study areas, including (i) how specific drought events are framed, and (ii) what is and is not reported about individual droughts across different source types. We conclude that different source types in the subcontinent may be more or less appropriate for addressing the specific objectives of historical climatology, particularly in relation to historical drought. Sources such as newspapers and weather diaries are rich in qualitative and quantitative observations suitable for the reconstruction of temporal and spatial patterns of weather and climate, as well as climaterelated natural disasters. In contrast, letters, reports and personal journals, especially those written by missionaries, provide additional qualitative narratives through which to investigate the vulnerability of past societies and economies to climate variations, and to explore past discourses and social representations of climate. While studies of this kind have been published for European and American source types, this is the first systematic exploration of documentary sources for the historical climatology of Africa. It should therefore provide a guide for climate history studies elsewhere in the continent, or other regions where written records are absent prior to the arrival of European colonists.

\section{Keywords}

Historical climatology; climate history; drought; documentary evidence; southern Africa 


\section{Introduction}

Recent years have seen a growth in the number of pre-20th century climate reconstructions for regions beyond Europe, based upon qualitative accounts and/or early instrumental meteorological data contained within historical documents (the "archives of society"; Pfister et al., 2018). This includes investigations in previously under-researched areas such as the tropics and sub-tropics (see Nash and Adamson, 2014; Adamson and Nash, 2018; del Rosario Prieto and Rojas, 2018; Ge et al., 2018; Gergis et al., 2018; Nicholson, 2018; White, 2018). For Africa, such reconstructions include new chronologies of temperature and rainfall variability (e.g. Kelso and Vogel, 2007; Grab and Nash, 2010; Nicholson et al., 2012; Nash et al., 2016), and cyclone intensity and periodicity (e.g. Nash et al., 2015), at regional to continental scales.

These types of investigation fall within the first objective of historical climatology, as defined by Brázdil et al. (2005; p.366) - to "reconstruct temporal and spatial patterns of weather and climate as well as climate-related natural disasters for the period prior to the creation of national meteorological networks". However, comparatively fewer studies have addressed the other objectives of the sub-discipline from an African perspective - to investigate the vulnerability of past societies to climate variability and extremes, and to explore past discourses and societal representations of climate. Notable exceptions include Eldredge (1993), Endfield and Nash (2002a, 2002b), Kelso and Vogel (2015), Hannaford (2018) and Klein et al. (2018).

The extent to which it is possible to reconstruct climate, understand human vulnerability to climate variability, and explore discourses of climate from an historical perspective, is contingent upon the nature of evidence within available written records. The archives of society tend to be heterogeneous, and the data they contain are often scattered over time and space (Brönnimann et al., 2018). Preservation may be patchy and access to documents difficult (making data rescue and digitisation efforts a high priority; Allan et al., 2016). Any qualitative information about weather and climate has usually been "coded" by individuals (Pfister, 2018; p.37) and necessitates content-specific interpretation. Further, there is often an emphasis on extreme events over 'normal' conditions in written descriptions (cf. Hassan, 2000), and it is sometimes difficult to determine the intensity, amount or duration of phenomena such as rainfall unless specified by observers (Pfister and White, 2018). To utilise documentary sources for climate history research requires knowledge of who produced them, their frame of reference, why information was documented, and how meteorological conditions and their societal consequences were recorded (e.g. Bell and Ogilvie, 1978; Duncan, 1997).

Over the course of more than 25 years' experience of historical climatology research in southern Africa, we have identified that different historical source types contain contrasting 
narratives and categories of information. The aim of this study is to evaluate the relative usefulness of four of the most widely available source types for Africa - newspapers, letters, reports and diaries - for addressing the three objectives of historical climatology research outlined above. This is achieved through an analysis of descriptions in different source types of three multi-year drought events that affected large areas of the southern African summer rainfall region during the mid-late 19th century, namely the droughts of 1861-63, 1876-79 and 1895-97 (Fig. 1). The analysis draws upon data from four case study areas - present-day KwaZulu-Natal (South Africa), Lesotho, Malawi, and the southern Kalahari (Botswana and South Africa) investigated as part of a series of interdisciplinary climate history projects. These case studies have been selected as they offer the opportunity to compare accounts of the same historical climate event across a variety of source types. We explore issues including how climate events are framed, and what is/not reported about events in different sources. Finally, consideration is given to the impacts of source type selection on the nature of the research themes that can be explored in specific areas and for different time periods.

(Fig. 1 here)

While studies of this sort have been published for European and American source types (see Pfister, 2018; Pfister and White, 2018), this is the first time that such a systematic exploration of documentary sources for historical climatology has been undertaken for the African continent. This paper should therefore provide a guide for similar studies elsewhere in Africa, or in other regions where a written documentary record is either absent or extremely limited before the arrival of European colonists.

\section{Sources and methods}

The collections of historical materials analysed for each of the four case study areas are presented in Table 1, along with the abbreviations used for collections in the footnotes in section 3. The majority of materials are what Pfister (2018) and Pfister and White (2018) term 'personal sources' (i.e. written by individuals), with a minor proportion of 'institutional sources' (i.e. created by colonial authorities). Nineteenth century materials from each collection were analysed systematically for (i) direct accounts of weather and climate, (ii) indirect climatic indicators such as droughts, floods and harvest quality/quantity, and (iii) accounts of the repercussions of climate variability for individuals and communities. These were recorded verbatim, translated into English where necessary, coded, and entered into a bespoke database. For this study, analysis focussed only upon information concerning the drought events of 1861-63, 1876-79, and 1895-97. As shown in Fig. 1, these were the most widespread multi-year droughts to affect southern Africa during the latter 19th century. Multiproxy 
reconstructions combining annually-resolved precipitation proxies from both natural and societal archives further indicate that the 1861-63 drought was the most severe of the 19th century (Neukom et al., 2014; Nash et al., 2016; Nash, 2017).

(Table 1 here)

Newspapers for the case study areas are rare during the periods of interest, so only a small number of titles were analysed. The most important was the Natal Witness (first published weekly in Pietermaritzburg in 1846, but daily by 1861), which continues today as The Witness. Much of the weather-related content of early issues concerned Pietermaritzburg and environs, until the mid-late 19th century when the network of reporters expanded to cover much of former Natal and Zululand (now KwaZulu-Natal). Other notable titles include Leselinyana la Lesotho (monthly, 1863 onwards) and Little Light of Basutoland (monthly, 1872-1877) for Lesotho, and The British Central African Gazette (monthly, 1894-1907) and The Central African Planter (monthly, 1895 onwards, published today as The Daily Times) for Malawi. All of these newspapers were written by Europeans, and hence could be considered 'external' to African society; however, as noted in section 3.1, Leselinyana la Lesotho was written specifically for an African audience. While the London Missionary Society (LMS) published newsletters such as Molekudi wa Bechuana in the mid-19th century, newspaper coverage of the southern Kalahari, including present-day Botswana, was limited until the early 20th century (Jones, 2015).

The majority of letters and reports analysed were unpublished official and personal documents written by Protestant missionaries. The earliest missionary activity in the case study areas was by the LMS, which established a mission at Lattakoo in the southern Kalahari in 1816 and had a network of stations by 1861 (Lovett, 1899). The Wesleyan Methodist Missionary Society (WMMS) started work at Platberg, northwest of present-day Lesotho, in 1825 (Findlay and Holdsworth, 1921-1924), followed by the Paris Evangelical Missionary Society (PEMS) at Makhoarane (present-day Morija) in 1833 (Eldredge, 1993). In KwaZulu-Natal, the first mission stations of the American Board of Commissioners for Foreign Missions (ABCFM) were established near Port Natal (Durban) and in Zululand in 1836 (Lulat, 2008). Other mission stations were founded during the 1840s and 1850s by the WMMS (Pritchard, 2013), Norwegian Mission Society (Hale, 1997), Hermannsburg Missionary Society (Lüdemann, 2000), and the Society for the Propagation of the Gospel in Foreign Parts (SPG) (Pascoe, 1901). In Malawi, representatives of the Universities' Mission to Central Africa (UMCA), Free Church of Scotland, and established Church of Scotland, founded mission stations in 1861 (at Magomero), 1875 (Cape Maclear), and 1876 (Blantyre), respectively (see Nash et al., 2018). In general, the volume of letters and reports written by missionaries in each case study area increased over time with the expansion of the missionary network. 
Most missionary letters and reports were dominated by accounts of local events. Individual missionaries carried out evangelical and other work at their appointed mission stations, and made only occasional visits to major towns/cities (e.g. for supplies and during furlough) and other missions (e.g. for annual conferences). Descriptions of exploratory excursions were limited, with the exception of Malawi where missionary activity was in its relative infancy in the mid-19th century and sites for new mission stations were still being sought. Accounts were mainly first-hand, although some sources contain 'provincial-scale' knowledge gained either through travel or interaction with others.

Other letters and reports related to the activities of colonial authorities and commercial enterprises; these increased in abundance in each study area following the onset of colonial rule. Materials included the published 'Blue Books' for the British colonies of Natal and Basutoland (Lesotho) and, in the case of Lesotho, the unpublished quarterly hand-written reports that fed into these annual summaries of colonial activity. These sources provided useful retrospective accounts of whole rainy seasons. Commercial reports for Malawi included records of various coffee plantations and the African Lakes Company Ltd, which operated transportation vessels on Lake Malawi during the late 19th century. Weather-related content in these sources ranged from short-term to seasonal.

Diaries/journals used for the four case study areas were written for a variety of purposes. As with missionary letters/reports, most diaries/journals were kept by observers who were primarily fixed in a particular place, with only a limited number of traveller/explorer diaries (relating mainly to Malawi). The number of available diaries varied between case study areas and over time, and appeared to reflect document survival. For KwaZulu-Natal, the majority of diaries analysed were kept by settlers, farmers, and military personnel. Although small in number, many are effectively "weather diaries" (see Adamson, 2015; Pfister, 2018; Pfister and White, 2018) with daily meteorological entries (sometimes in pre-printed almanacs), while others comprise freehand personal journals. For Malawi, diaries include the personal journals of European explorers (notably former LMS missionary David Livingstone and members of his expedition teams) and missionaries. Detailed station journals also survive for many of the earliest missions in Malawi. These followed general instructions issued by the Foreign Missions Committee of the Free Church of Scotland, that were formalised in a printed pamphlet in 1875:

"For some considerable time - perhaps for two or three years - a Daily Journal should be kept, recording all matters of general interest, and specially, records of daily temperature (three observations if possible), atmospheric changes, the setting in of rain, the directions of winds, the kind of daily employment engaged in by the staff, and immediately following on this, a statement on the health of the party... State facts only at first - give inferences after a time when there appear to be sufficient data to explain 
any illness, as the connection between kind of weather, work and diet, or special exposure [...] It may appear as if undue importance were being attached to this part of the instructions, but it will probably be discovered that on correct information of this kind the welfare and continued success of this Mission is greatly dependent. We know as yet too little of the causes which influence health in that country." 1

In Lesotho, the main diaries were by missionaries and colonial authorities. The longest running of these was the daily diary of Sir Godfrey Lagden, the British Resident Commissioner for Basutoland, spanning the period 1884-1900. For the Kalahari, small numbers of personal journals are preserved for LMS missionaries but none encompass the selected drought episodes.

\section{Accounts of droughts}

This section presents the contrasting ways in which the droughts of 1861-63, 1876-79 and 1895-97 were narrated in different historical source types. For each event, evidence is considered by source type as follows: newspapers, letters and reports, and diaries/journals.

Differences between source types are summarised in section 4.

\subsection{Descriptions of the 1861-63 drought}

Drought conditions appear to have affected much of the southern African summer rainfall region (with the exception of central Namibia) during the rainy seasons of 1861-62 and 1862-63 (Fig. 1). Newspaper accounts are especially rich sources for various aspects of climate reconstruction at the time. For example, the Natal Witness (September 1861) provides a narrative account of the delayed onset of the 1861-62 austral summer rainy season and its impact on pasturage across former Natal:

"The rains due this month have not yet set in, and the country in many parts is very much parched. In the Umgeni regions, it is said, sheep have not been so healthy this season. In the upper countries the flocks are said to be in a more satisfactory state." 2

and also gives a sense of the relative severity of drought conditions:

"Slight rains have fallen, but not sufficient to satisfy the thirst of nature created by the long drought. This is said to be one of the driest seasons known for many years." 3

\footnotetext{
${ }^{1}$ National Library of Scotland Dep.298/139 Livingstonia. Instructions to Lake Nyassa Mission Party from Foreign Missions Committee of the Free Church, with concurrence of Committee of Reformed Presbyterian Church.

${ }^{2}$ Natal Witness, 13 September 1861

${ }^{3}$ Natal Witness, 27 September 1861
} 
Some newspaper articles also comment specifically on the spatial variability of rainfall, although these are less common. For example, an issue of the Natal Witness describing the start of the 1862-63 rainy season noted:

"Within the last few days some acceptable showers have fallen around the city, but it is feared they have not extended far inland, where they are so much-needed. No ordinary Natal rains have as yet come down this season. It is probably not within the recollection of any colonist that September and October have before passed over without frequent splendid storms" 4

Newspaper accounts covering the impacts of reduced rainfall, human vulnerability, and associated societal responses are relatively limited, and mainly occur during the latter stages of each rainy season when the effects of agricultural drought were felt most severely. Most accounts focus on impacts upon colonists, with only rare examples discussing the implications for black African populations:

"The long-continued drought that we have experienced has made vegetables scarce and dear. I saw a cart come into Ladismith [sic] the other day bringing in onions and cabbages from a farm thirty miles off, and notwithstanding the high prices [...] they sold fast; in fact, women, children, and Kafirs might be seen rushing up the principal street to make sure of getting some of this green meat." 5

An exception is the Sesotho-language newspaper Leselinyana La Lesotho, written and published by Paris Evangelical Missionary Society missionaries and targeted at literate local inhabitants (Kunene, 1977). An article from November 1863, for example, notes social responses to drought in the form of religious practices:

"The Lord has been merciful on us and given us rain so we can plough and plant food this season. Last year was very dry and chiefs were calling for priest to pray for rain." 6

Accounts of adaptations to drought are equally rare in newspapers. One exception is a plea in the Natal Witness at the height of the drought for the introduction of irrigation:

"Sir, I painfully exclaim, no new grass in the principal grazing districts of Natal, where, in favourable seasons, the best cattle, the best mealies (corn/maize], and the best wheat are produced? For nearly three years we have been sufferers by drought, which friendly visitors from the South-West say goes towards establishing this as a sheep country [...] It is neither a good sheep country, cattle country, grain country, or good for anything else; neither will it be unless we assist nature. These never-failing rivers can be diverted easily from their course high up towards their sources, and be made to wind about along the surface of the country, always keeping high levels, to irrigate nearly the whole of the available cultivable land from the Drakensberg to the coast." 7

\footnotetext{
4 Natal Witness, 24 October 1862

5 Natal Witness, 19 January 1863

6 Leselinyana La Lesotho, 3 November 1863, p.3 (translated from the original Sesotho)

7 Natal Witness, 19 September 1862
} 
In comparison with newspapers, missionary letters and reports contain proportionally fewer descriptions of weather conditions. However, narrative accounts within individual missionary documents can provide equivalent depth to newspaper articles. Compare, for example, the following extract from a letter written by the SPG Bishop Colenso based in Pietermaritzburg with the quote from the Natal Witness for September 1861 above:

"The season has been an unusually dry one. Our winters are, indeed, always dry, so that for weeks together the sky is clear, and we have no rain. But, generally, there are heavy showers for a few days in midwinter, and rain again in the early part of September - all which has this year been wanting..." 8

The real strength of missionary letters and reports is the insight they can provide into the impacts of, and responses to, drought amongst both mission and local communities, and the factors influencing vulnerability amongst different sectors of society. Perhaps unsurprisingly, most initial descriptions of the 1861-63 drought within missionary writings focus upon environmental conditions, with increasing numbers of accounts of societal repercussions as meteorological drought conditions worsened and agricultural and/or hydrological drought loomed. The following quote is typical of those discussing responses and local adaptations to drought in the southern Kalahari, providing details of population migration due to water shortages:

[The BaTlhaping people] "...formerly of the Kuruman [...] have been compelled to vacate those places from the insufficiency of water and are seeking another locality. At present, they are making a temporary stay at llosi about 30 miles north of this place and are only waiting till the rains to be able to proceed further into the interior and may eventually settle down in the neighbourhood of the Molopo River." 9

Accounts of temporary population dispersal in search of food also occur, such as this example from Zululand:

"I am afraid we are going to have another year of famine. In some districts the crops are an utter failure and the people have dispersed themselves elsewhere in search of food. One party has passed this place and I saw another at Entseleni." 10

Alternative livelihood strategies during the drought are also discussed, such as this evidence from Lesotho:

"Our people do not have any sort of provisions to live. They only have a little dairy since the rains, because before the cattle, who did not yield any as result of lack of food, could hardly stay alive. Like after the war of 1858 the hunger pushes the people to eat roots to live." 11

\footnotetext{
8 USPG D25a, Bishop Colenso, Maritzburg, 28 September 1861

${ }^{9}$ LMS Correspondence 32-5-B, R. Moffat, Kuruman, 1 December 1862

10 USPG E9a, R. Robertson, Kwamagwaza, 7 April 1862

${ }^{11}$ PEMS Africa Australe FBN4 Mf.199. L.J. Cochet, Hébron. 6 February 1863 (translated from the original French)
} 
Missionary accounts also provide unique insights into cultural and religious responses to the drought. Klein et al. (2018), for example, provide considerable detail about rain-control and rainmaking practices in former Natal and Zululand. These are elaborated upon by the German missionary Otto Heinrich Röttcher, of Mhlangana mission in Zululand, who described how a rain doctor was called for from north of the Drakensberg, following the failure of 1862-63 rainy season ${ }^{12}$. Accounts of similar practices appear for other case study areas, such as this extract from LMS missionary John McKenzie, writing near present-day Serowe, Botswana, of the hostility of the Barolong Chief towards Christian converts:

"The worst cause of offence was the refusal of the Christian young men and enquirers to go to the hunt as usual. This was followed by another 'crime', their refusal to join in the digging 'the garden of rain' (tsimo ea pula). This is as you are aware a heathen ceremony, and those who take part in it are of course abettors of rain-making." ${ }^{13}$

Where multiple missionary societies operated in the same area, it is possible to detect both similarities and differences in the material covered within their collective letters and reports. During the 1861-63 drought, documents written by WMMS missionaries in Lesotho include more information about matters affecting local populations than those written by PEMS missionaries, whose accounts were largely about environmental impacts. However, missionaries from both societies provide information about rainmaking practices.

Diaries spanning the 1861-63 drought tend to be dominated by weather descriptions. The diaries and letters from the Second Zambesi Expedition (1858-1864), led by David Livingstone, for example, provide the only climate information for Malawi at this time (Nash et al., 2018). If weather observations in diaries were made daily, they can be potentially useful for aspects of climate reconstruction, e.g. frequency counts of days with/without precipitation, start/end dates of rainy/frost seasons (see Adamson 2015). Although relatively few in number, farmers' diaries are particularly good in this respect, as this extract from the 1862 diary of John Blamey, a farmer from Verulam, near Durban, illustrates:

[January 1, 1862] "Heavy rain this day"

[2.] "Weather fine"

[3.] "Weather exceedingly hot"

[4.] "Weather fair"

[5.] "Weather fine during morning and exceeding hot, rain in the afternoon"

[6.] "Weather dull during the day, weather fine night"

[7.] "Weather warm during the day, weather fine night"

[8.] "Weather fine as regards dry during the day, thunder and lightning but little rain at night" 14

12 ELM, ASA 41, 94, Müden/Natal, 1865-1905

${ }^{13}$ LMS Correspondence 32-5-A, J. McKenzie, Bamangwato, 27 June 1862

${ }^{14}$ Killie Campbell manuscript 98/6/1/3. John Cardell Blamey. Farm Stats/Weather 1850-62, Diary 1871, Diary 1872. 
There are, however, differences in the coverage of societal impacts and responses in diaries written by different categories of author. For example, most farmers' diaries from the case study areas contain relatively little about the ways that people coped during the early 1860 s drought. In contrast, missionary journals can be rich with social detail and in many respects are similar in their coverage to missionary letters and reports.

\subsection{Descriptions of the 1876-79 drought}

Drought conditions during the late 1870 s affected much of the southern African summer rainfall zone, although the drought does not appear to have been as universally severe as in 1861-63 (Nash et al., 2018). A very similar pattern of reporting to the 1861-63 drought is observed across the different source types for the four case study areas.

Newspaper coverage continued to provide information of a type suitable for climatic reconstruction. Multiple titles were now available for Lesotho. For KwaZulu-Natal, increasing spatial detail can be obtained due to the expanded network of regional correspondents reporting into the editorial office of the Natal Witness. Rather than accounts being dominated by weather descriptions from Pietermaritzburg and Durban, articles include reports from as far apart as Kokstad in southernmost Natal and Newcastle in the north. Reflecting the "quantitative turn" in meteorology (Pfister, 2018; p.40), these reports often incorporate instrumental data. The first measured meteorological data for Durban appeared in the Natal Witness from August 1850 (Nash and Adamson, 2014; Nash, 2017) until February 1853; weekly summaries of barometric, temperature, wind direction and rainfall data for Pietermaritzburg were published from January 1870 onwards.

Contrasts in the coverage of societal aspects of drought between newspapers aimed primarily at white and black African audiences remain apparent, as illustrated by this extract from the Little Light of Basutoland:

"The drought has been very much felt in several parts of Basutoland: at some places the stalks of Kaffircorn [sorghum] and mealies [corn/maize] have been, as it were, calcinated by the sun: many fields are completely destroyed: others have been very much spoilt by the hail, so that there may be a dearth of food in the country. Several chiefs, therefore, have been driven during the past weeks to the usual heathen practices which are recommended by the rain-makers of the country..." 15

\footnotetext{
15 Little Light of Basutoland No 2 February 1877, p.1
} 
Missionary writings continue to report on short- and long-term weather variability, drought impacts and responses among local populations. For example, the WMMS missionary John Parsonson, of Thaba Nchu mission, northwest of Lesotho, observed in a letter of July 1877:

"...there is much suffering in the tribe. The last summer having been a long drought the crops of Kaffir corn [sorghum] and mealies [corn/maize] have to a large extent failed. Hence our people have not food for the winter and are leaving to seek service among the Dutch farmers in the Free State. Trade too is almost at a standstill." 16

Missionaries also reported on experimental measures to be taken by Europeans at the Livingstonia mission, Malawi, to deal with the vagaries of climate and its impacts on food supply:

"The main attention should be devoted to wheat, sugar and oil seeds, and as much green maize and other garden vegetables - along with some of the fruits of the country such as bananas - as will afford a daily supply for the table. The chief object in this department in reference to the garden is to secure variety in the diet, with the view to the preservation of the health of the whole party. The essential point to be found by experiment is, the best months for sowing and ripening of wheat and other foreign grains. In ordinary years it will be found cheaper to buy dried grain, maize, mapira [sorghum], and rice from the natives than to grow it at present. This encourages production, and benefits the natives by the exchange of cloth, and also by bringing them frequently to the station." 17

Available diaries for the case study areas mainly focus on day-to-day weather with little reflective commentary on climate impacts/responses. Exceptions again are a small number of long-form journals, as illustrated by this diary entry of 9 November 1878 by John Gunn of the Livingstonia mission, Malawi, commenting on drought and tsetse fly:

“This afternoon I had a walk round the plain. It occupied me three hours' hard walking [...] Large areas of the plain are being brought under cultivation by the natives, yet much fairly good soil remains available. It seems to me that tsetse are visibly diminishing. This may, however, be more attributable to the parched state of the plain, consequent on the severe drought of last season, than to the fact that we are encroaching on their haunts and driving them away." 18

The expanded network of news correspondents reporting to the Natal Witness permits a comparison of the focus of newspaper articles, missionary narratives and diaries. Although writing on virtually the same day, at locations less than $100 \mathrm{~km}$ apart, the Natal Witness provides a superficial account of one day's rainfall in Greytown and its impacts on settlers:

\footnotetext{
${ }^{16}$ WMMS South African Correspondence FBN6 Mf 189. J. Parsonson, Thaba Nchu, 24 July 1877

17 National Library of Scotland Ms.7904 Livingstonia. Summary of Instructions and Hints for 1878 (by James Stewart)

${ }^{18}$ National Library of Scotland Ms.7906/11-20 The Late Mr Gunn's Diary at Livingstonia
} 
"Greytown. The usual quarterly Nachtmaal [holy communion] was held in our Dutch Church last Sunday [29 October 1876] [...] Under the circumstances the cold rain on Sunday night must have been unpleasant, to say the least of it." 19

In contrast, SPG missionary Joel Jackson offers greater climatic context and detail of the societal repercussions and responses to the ongoing drought at KwaMagwaza mission:

"The rains this season are very late, and consequently people are not able to plant and everyone is becoming most anxious. The Amanwazi king is thought to be the great Rain Doctor in this part but he has just taken a number of wives and is said to want cattle to pay the ukulobola or marriage arrangement, so he refuses to give rain until the people have presented him with the requisite numbers of cattle." 20

Newspaper reports can also be used to aid in the interpretation of diary entries. For example, it is difficult to tell from the diary by Zululand farmer James Milkley for December 1877 that a drought is in progress:
[2. December 1877] "Very hot day"
[3.] "Very hot day"
[4.] "Rainy day"
[5.] "Windy morning rain at night"
[6.] "Wet day"
[9.] "Rain in evening" 21

Only more reflective newspaper articles, such as the following from the Natal Witness, reveal the characteristics of rainfall at the time as being relatively light, if frequent:

"Newcastle. Nice rains have fallen, but not soakers. In fact we have not had a proper soaking rain since last autumn. Except just under the Berg, crops are a total failure, and a scarcity of mealies [corn/maize], etc., is expected." ${ }^{2}$

\subsection{Descriptions of the 1895-97 drought}

Although not extending as far north as Malawi, the mid-late 1890s drought appears to have affected much of the southern African summer rainfall zone, and to have been the most protracted of the 19th century (Fig. 1). It also coincided with other stresses, including locust outbreaks and, in 1896, the rinderpest (cattle plague) epidemic which killed more than 5.2 million cattle south of the Zambesi, thereby affecting transport and indigenous nutritional sources (Pribyl et al., 2018, in review).

\footnotetext{
19 Natal Witness, 3 November 1876

20 USPG E31, J. Jackson, Amanvazi, Zululand, 31 October 1876

${ }^{21}$ Killie Campbell manuscripts, Natal Almanac (1876) The Natal Almanac, Directory and Yearly Register 1877 (includes diary entries by James Erasmus Milkley, from Newstead, Curry's Post). P. Davis and Sons, Pietermaritzburg.

22 Natal Witness, 29 January 1878
} 
Newspapers for this period are by far the most useful source for spatial climate reconstruction, including rich geographical detail, often backed up with reference to rainfall data, as illustrated by this extract from the Natal Witness from 1895:

"Rainfall here [Pietermaritzburg] for November [1895] has totalled 5.6 inches on 16 days. This amount has been plenty for just here, but I hear complaints all around that ploughing is again having to stop for want of moisture. The above amount is 2.05 inches below the average of the last four years, which is 7.67 on 19 days. Rain has been very partial." 23

Throughout this period, missionaries continue to report front-line climate information, and provide greater detail about drought impacts on local populations, and their associated responses, than newspapers. The Norwegian missionary Ole Steenberg, for example, reported the combined impacts of agricultural drought and locusts upon the people of Mahlabatini, Zululand, in 1895, and their associated responses to the resulting food shortages:

"The Lord spoke to us last year by sending drought on our crops, and this year he has spoken even more strongly by completely destroying all that was sprouting in our fields. On the 15th January of this year, the locusts came to Ematlabatini and devoured all the crops on the ground [...] When the imported corn from America came up to Zululand it was expensive. And what could they buy it with? They only had their cattle and they could have purchased only one or two bags per animal depending on its size. If they purchased corn according to their needs, they saw that they would soon get rid of their cattle, their only livelihood, as the cattle milked well in the summer and at least gave them a living. Then a revolution occurred, a radical process of dispersal among the people: quite a few went to Natal and Johannesburg to find work in order to provide an income for their homes; others scattered around the country, partly to beg, partly to find temporary shelter with relatives or acquaintances." ${ }^{24}$

The German missionary David Wolff of Ekulangeni, Zululand, identified differential impacts of agricultural drought between white and black populations at the mission in late 1895, and also noted government-level responses:

"[...] we suffered from the drought at the beginning of the summer. The rain, which usually starts in August, came this year only in November. As a result, no one could prepare their fields before November. The effects of the drought were greater for the black people than the whites [...] After the rain had stayed away for so long, the government declared a day of prayer, which was to be observed throughout the country. We had one here too." 25

The majority of diaries again focus on daily weather, and rarely comment on the impacts of drought. One exception is the diary of Sir Godfrey Lagden, who reported extensively on daily life, both in Maseru, Lesotho, and during his travels. This extract from his journal for

\footnotetext{
${ }^{23}$ Natal Witness, 5 December 1895

${ }^{24}$ MHS, Mission Archives, A1045-140b-8 Steenberg, 15 August 1896 (translated from the original Norwegian)

${ }^{25}$ ELM, Missionsblatt 43/6, Hermannsburg 1896, 58-61 (translated from the original German)
} 
November/December 1897 describes the impact of drought in western Lesotho, and provides the date of what Lagden perceived to be the end of the drought:

[28 November 1897] "Very hot day. Flies awful."

[1 December 1897] "Cloudy day. Rain promises well."

[2.] "Reached Mafeteng at 1. Deplorable drought which is now becoming alarming."

[3.] "At Mafeteng. The fear of famine is great."

[4.] "Returned to Maseru. Frightfully hot. The want of rain is terrible. The Caledon,

Matyatsana and Little Caledon [rivers] are dry."

[5.] "Frightfully hot and water famine alarming."

[6.] "Very warm day. The drought is terrible."

[8.] "Terribly hot day and drought awful."

[9.] "Warm day. Threatening storm but no results."

[11.] "The drought is awful."

[18.] "Rain in afternoon. Drought broken."

[20.] "Heavy rain. Drought quite broken up."

[22.] "Nice raining." 26

\section{Relative usefulness of different source types for historical climatology}

The parallel analysis of descriptions of drought events in newspapers, letters, reports and diaries presented here draws out some notable differences in coverage between different historical source types (Table 2). In part, these stem from the original purpose of each source type and its intended audience.

(Table 2 here)

\subsection{Newspapers}

As is the case today, the 19th century newspapers examined during this study primarily reported 'news' and attempted to shape opinion. The titles analysed were by far the most rich sources of information about day-to-day weather and longer-term climate variability through which to identify meteorological drought. Articles included accounts of the onset of rainy seasons and the relative abundance of seasonal rainfall. In the Natal Witness, these observations tended to be localised to the Pietermaritzburg area in earlier editions of the newspaper, but the potential for spatial rainfall reconstruction increased over the course of the 19th century. The earliest meteorological data for southeast Africa also appeared in the newspaper. We would echo White (2018, p.41) in stating that newspapers are potential "goldmines for weather observations" in African and other global contexts where instrumental meteorological records are scarce or absent.

${ }^{26}$ Bodleian Library MSS.Afr.s.170, Sir Godfrey Lagden Diaries 
The newspapers analysed here offered significantly less information about the societal repercussions of individual drought episodes. This is perhaps not surprising as there are commonly time-lags between a reported problem and any organised response, unless the response is made at a local level. There were, however, differences in coverage according to the newspaper's intended audience. The Natal Witness usually provided only brief accounts of drought impacts, and then mainly where conditions were likely to negatively affect agricultural activities or lead to dust storms (and hence be of interest to farmers and urban populations). Exceptions occurred when there was potential for political capital to be gained through reference to drought (e.g. the plea for irrigation in Natal during the 1861-63 drought; section 3.1). In contrast, Leselinyana la Lesotho and Little Light of Basutoland, written by French missionaries and targeted at black African audiences, provided greater reflection on the impacts of, and responses to, drought at mission stations and surrounding villages.

All newspapers suffered from inherent colonial biases, however, and must be read with caution. This can be overcome by reading sources "against the grain" (Hazareesingh, 2013; p.99) to identify the local voice within the narratives. Coverage of weather events and their repercussions also declined during periods of war or other political upheaval. In summary, while newspapers do include information relevant to the second and third objectives of historical climatology (sensu Brázdil et al., 2005), titles that incorporate dedicated sections for farmers, and/or are targeted at African audiences, are likely to prove the most useful in this respect.

\subsection{Letters and reports}

As today, the letters and reports analysed were predominantly intended to be informative and were sent for a purpose. However, the information included varied between, for example, personal letters to family and friends, personal or semi-official letters to other missionaries, and more official correspondence with missionary headquarters. Weather observations within official missionary (and other) letters and reports can be sufficiently detailed to permit the identification of meteorological, agricultural and, on occasions, hydrological drought, in the absence of other sources (cf. Endfield and Nash, 2002b; Nash and Endfield, 2002). However, in comparison with newspapers, descriptions of weather conditions are less frequent within missionary writings from our case study areas.

Missionaries were, in general, excellent observers of people. As such, their letters and reports offered the greatest potential for understanding differential vulnerability and the impacts of, and responses to, drought among African societies (particularly those affected by colonial intrusion). This potential increased over time with the increasing volume of missionary materials. Indeed, we would recommend historians interested in the repercussions of past extreme climate events 
in Africa (and other regions of the tropics and subtropics) to seek out missionary collections above all others. However, caution is needed. The missionary societies working in our case study areas differed in the socio-economic and educational background of the missionaries they recruited. Further, the background of mission personnel changed over the course of the 19th century as the missionary role professionalised (cf. Semple, 2004). More importantly, while most mission stations were in rural areas, some were located in larger population centres. These factors have implications for what was included in letters and reports to their respective mission headquarters. The majority of Norwegian missionaries in KwaZulu-Natal, for example, were from rural western Norway, had farming, fishing or artisanal backgrounds, and were based among rural communities (Hale, 1997). Consequently, much of the non-religious content of mission correspondence focussed upon rural affairs, such as daily labour on the farm, the seasonal harvest, and, occasionally, plant-phenological observations (see Pfister and White, 2018). The same is true of the German Hermannsburg mission, which had a predominantly rural focus (Lüdemann, 2000). In contrast, missionaries based in larger population centres (e.g. SPG missionaries in Pietermaritzburg), tended to comment more on local and colonial politics, unless there were major agricultural crises that affected food prices and availability in the urban area. However, as illustrated by comparing social commentaries of missionaries working for the WMMS and PEMS in rural Lesotho (section 3.1), it is inadvisable to generalise. A key finding here is the need to research the mission goals, recruitment policies and spatial distribution of mission stations before embarking on an analysis of missionary archives from an historical climatology perspective.

\subsection{Diaries/journals}

Diaries and journals for our case study areas varied in their usefulness for climate reconstruction and the analysis of societal repercussions. Most were not intended for public consumption, although the personal journals of leading figures would sometimes be published. Those that are weather diaries with brief daily entries, while less useful for understanding relative rainfall abundance, offer potential for the generation of quantitative or semi-quantitative information such as frequency counts of days with/without precipitation and the start/end dates of rain/frost seasons. Records kept by 'static' (as opposed to traveller) diarists are most useful in this respect. Those in the form of freehand personal journals often contain highly individualised thoughts and reflective notes, acting almost as a kind of confessional. These types of journal offer the potential for obtaining environmental data, societal observations, and cultural information on the author's climate perceptions - what Ingold (2011) and Adamson (2015) refer to as their interaction with the "weather world" - as well as prevailing climate discourses. The early mission station journals from Malawi, where missionaries were encouraged to include rich environmental detail (see section 2), are a hybrid 
personal/institutional equivalent of this type. Care is needed, however, when interpreting diary/journal entries by missionaries and colonists. It is important to understand (i) the nationality and background of the diarist (which may influence their perception and description of climatic conditions), (ii) whether they were a traveller/explorer or mainly static (which may affect the geographical scope of their observations), and, if static, (iii) their length of residence in a region (which may shape their familiarity with local cultures and weather conditions, and hence their long-term view on climatic variability and any associated societal repercussions) (cf. Bryson and Padoch, 1980; Hassan, 2000). The same can be true of many personal letters.

\section{Conclusions}

This paper set out to evaluate the usefulness of newspapers, letters, reports and diaries for addressing the objectives of historical climatology research from an African perspective. The main conclusion is that no one historical source type, perhaps with the exception of missionary letters and reports, is suitable to meet all three objectives. Further, the potential to address the different objectives of historical climatology will vary over time according to the availability of different historical source types. In all of our case study areas, as with many regions of the tropics and subtropics that lack a long written tradition, some of the earliest available sources were isolated letters and reports written by early explorers and settlers. Reconstructing climate variability for these earlier periods is challenging, owing to the low frequency of weather observations in such sources; it may, however, be possible to explore social aspects of climate. The arrival of missionaries, followed by other settlers and their associated media (i.e. newspapers), increased the availability of written documentation, and hence the potential to explore the wider climate histories of each area. Echoing Nash and Adamson (2014), there remain major geographic gaps in our understanding of the climate histories of Africa, most notably in the desert and equatorial regions of the continent; many of these gaps could be filled through targeted source-critical analyses of missionary and other historical materials. Even with the challenges of content-specific interpretation for some materials (see Pfister, 2018; Pfister and White, 2018), we would recommend the exploration of all available source types to gain the most detailed insights into historic climatic variability and its impacts upon individuals and societies in Africa. 


\section{Acknowledgements}

The primary archival work for this study was undertaken as part of British Academy Small Research Grants APN 29960, SG-35582 and SG-40838, and Leverhulme Trust Research Project Grant F/00504/D. We extend our thanks to the staff at all of the archives listed in Table 1, and to Stan Stanier for the creation of the ENSOAfrica database used to code and organise historical materials. Finally, we thank the three anonymous reviewers whose thoughtful and constructive comments greatly improved the manuscript.

\section{References}

Adamson GCD (2015) Private diaries as information sources in climate research. Wiley Interdisciplinary Reviews: Climate Change 6:599-611.

Adamson GCD, Nash DJ (2018) Climate history of Asia (excluding China). In White S, Pfister C, Mauelshagen $\mathrm{F}$ (eds.) The Palgrave Handbook of Climate History. Palgrave Macmillan, London, pp. 203-211.

Allan R, Endfield G, Damodaran V, Adamson G, Hannaford M, Carroll F, Macdonald N, Groom N, Jones J, Williamson F, Hendy E, Holper P, Arroyo-Mora JP, Hughes L, Bickers R, Bliuc AM (2016) Toward integrated historical climate research: the example of Atmospheric Circulation Reconstructions over the Earth. Wiley Interdisciplinary Reviews-Climate Change 7:164-174.

Bell WT, Ogilvie AEJ (1978) Weather compilations as a source of data for reconstruction of European climate during Medieval period. Climatic Change 1:331-348.

Brázdil R, Pfister C, Wanner H, von Storch H, Luterbacher J (2005) Historical climatology in Europe - the state of the art. Climatic Change 70:363-430.

Brönnimann S, Pfister C, White S (2018) Archives of nature and archives of society. In White S, Pfister C, Mauelshagen F (eds.) The Palgrave Handbook of Climate History. Palgrave Macmillan, London, pp. 27-36.

Bryson R, Padoch C (1980) On the climates of history. Journal of Interdisciplinary History 10:583-597.

del Rosario Prieto M, Rojas F (2018) Climate history in Latin America. In White S, Pfister C, Mauelshagen $\mathrm{F}$ (eds.) The Palgrave Handbook of Climate History. Palgrave Macmillan, London, pp. 213-224.

Duncan J (1997) Sites of representation - place, time and the discourse of the other. In Duncan J, Ley D (eds.) Place, culture and representation. Routledge, London, pp. 39-56.

Eldredge EA (1993) A South African Kingdom: The pursuit of security in nineteenth-century Lesotho. African Studies Series No. 78. Cambridge University Press, Cambridge.

Endfield GH, Nash DJ (2002a) Missionaries and morals: Climatic discourse in nineteenthcentury central southern Africa. Annals of the Association of American Geographers 92:727-742.

Endfield GH, Nash DJ (2002b) Drought, desiccation and discourse: missionary correspondence and nineteenth-century climate change in central southern Africa. Geographical Journal 168:33-47.

Findlay GG, Holdsworth WW (1921-1924) The History of the Wesleyan Methodist Missionary Society, 5 vols. Epworth Press, London. 
Ge Q, Hao Z, Zheng J, Lui Y (2018) China: 2000 years of climate reconstruction from historical documents. In White S, Pfister C, Mauelshagen F (eds.) The Palgrave Handbook of Climate History. Palgrave Macmillan, London, pp. 189-201.

Gergis J, Ashcroft L, Garden D (2018) Recent developments in Australian climate history. In White S, Pfister C, Mauelshagen F (eds.) The Palgrave Handbook of Climate History. Palgrave Macmillan, London, pp. 237-245.

Grab SW, Nash DJ (2010) Documentary evidence of climate variability during cold seasons in Lesotho, southern Africa, 1833-1900. Climate Dynamics 34:473-499.

Grab SW, Zumthurm T (2018) The land and its climate knows no transition, no middle ground, everywhere too much or too little: a documentary-based climate chronology for central Namibia, 1845-1900. International Journal of Climatology 38 (Suppl. 1):e643-e659.

Hale F (1997) Norwegian missionaries in Natal and Zululand: selected correspondence 18441900. Van Riebeeck Society, Cape Town.

Hannaford MJ (2018) Long-term drivers of vulnerability and resilience to drought in the Zambezi-Save area of southern Africa, 1505-1830. Global and Planetary Change 166:94106.

Hassan $F(2000)$ Environmental perception and human responses in history and prehistory. In McIntosh RJ, Tainter JA, Mclntosh SK (eds.) The way the wind blows: climate, history and human action. Columbia University press, New York, pp. 121-140.

Hazareesingh S (2013) Territories of conquest, landscapes of resistance: the political ecology of peasant cultivation in Dharwar, western India, 1818-1840. Journal of Historical Geography 42:89-99.

Ingold T (2011) Being alive: Essays on movement, knowledge and description. Routledge, London.

Jones D (ed.) (2015) Censorship: A world encyclopaedia. Routledge, New York.

Kelso C, Vogel CH (2007) The climate of Namaqualand in the nineteenth century. Climatic Change 83:257-380.

Kelso C, Vogel CH (2015) Diversity to decline-livelihood adaptations of the Namaqua Khoikhoi (1800-1900). Global Environmental Change 35:254-268.

Klein J, Nash DJ, Pribyl K, Endfield GH, Hannaford M (2018) Climate, conflict and society: changing responses to weather extremes in nineteenth century Zululand. Environment and History 24:377-401.

Kunene DP (1977) "Leselinyana la Lesotho" and Sotho historiography. History in Africa 4:149161.

Lovett R (1899) The History of the London Missionary Society, 1795-1895, 2 vols. Henry Frowde, London.

Lüdemann E-A (ed.) (2000) Vision: Gemeinde weltweit - 150 Jahre Hermannsburger Mission und Ev. Luth. Missionswerk in Niedersachsen. Verlag der Missionshandlung, Hermannsburg.

Lulat YG-M (2008) United States relations with South Africa: a critical overview from the colonial period to the present. Peter Lang Publishing, New York.

Nash DJ (2017) Changes in precipitation over southern Africa during recent centuries. Oxford Research Encyclopedia of Climate Science:

DOI:10.1093/acrefore/9780190228620.013.539.

Nash DJ, Endfield GH (2002) A 19th century climate chronology for the Kalahari region of central southern Africa derived from missionary correspondence. International Journal of Climatology 22:821-841. 
Nash DJ, Endfield GH (2008) 'Splendid rains have fallen': links between El Nino and rainfall variability in the Kalahari, 1840-1900. Climatic Change 86:257-290.

Nash DJ, Grab SW (2010) "A sky of brass and burning winds": documentary evidence of rainfall variability in the Kingdom of Lesotho, Southern Africa, 1824-1900. Climatic Change 101:617-653.

Nash DJ, Adamson GCD (2014) Recent advances in the historical climatology of the tropics and subtropics. Bulletin of the American Meteorological Society 95:131-146.

Nash DJ, Pribyl K, Endfield GH, Klein J, Adamson GCD (2018) Rainfall variability over Malawi during the late 19th century. International Journal of Climatology 38 (Suppl. 1):e629-e642.

Nash DJ, Pribyl K, Klein J, Endfield GH, Kniveton DR, Adamson GCD (2015) Tropical cyclone activity over Madagascar during the late nineteenth century. International Journal of Climatology 35:3249-3261.

Nash DJ, Pribyl K, Klein J, Neukom R, Endfield GH, Adamson GCD, Kniveton DR (2016) Seasonal rainfall variability in southeast Africa during the nineteenth century reconstructed from documentary sources. Climatic Change 134:605-619.

Neukom R, Nash DJ, Endfield GH, Grab SW, Grove CA, Kelso C, Vogel CH, Zinke J (2014) Multi-proxy summer and winter precipitation reconstruction for southern Africa over the last 200 years. Climate Dynamics 42:2713-2716.

Nicholson SE (2018) A multi-century history of drought and wetter conditions in Africa. In White S, Pfister C, Mauelshagen F (eds.) The Palgrave Handbook of Climate History. Palgrave Macmillan, London, pp. 225-236.

Nicholson SE, Klotter D, Dezfuli AK (2012) Spatial reconstruction of semi-quantitative precipitation fields over Africa during the nineteenth century from documentary evidence and gauge data. Quaternary Research 78:13-23.

Pascoe CF (1901) Two hundred years of the SPG: an historical account of the Society for the Propagation of the Gospel in Foreign Parts, 1701-1900. Society for the Propagation of the Gospel, London.

Pfister C (2018) Evidence from the archives of societies: Documentary evidence - overview. In White S, Pfister C, Mauelshagen F (eds.) The Palgrave Handbook of Climate History. Palgrave Macmillan, London, pp. 37-47.

Pfister C, White S (2018) Evidence from the archives of societies: Personal documentary sources. In White S, Pfister C, Mauelshagen F (eds.) The Palgrave Handbook of Climate History. Palgrave Macmillan, London, pp. 49-65.

Pfister C, White S, Mauelshagen F (2018) General introduction: Weather, climate, and human history. In White S, Pfister C, Mauelshagen F (eds.) The Palgrave Handbook of Climate History. Palgrave Macmillan, London, pp. 1-19.

Pribyl K, Nash DJ, Klein J, Endfield GH (2018, in review) The role of drought in agrarian crisis and social change: The famine of the 1890s in south-eastern Africa. Regional Environmental Change.

Pritchard J (2013) Methodists and their Missionary Societies 1760-1900. Ashgate, Farnham.

Semple RA (2004) Missionary women. Gender, professionalism and the Victorian idea of Christian mission. Boydell Press, Ipswich.

Therrell MD, Stahle DW, Ries LP, Shugart HH (2006) Tree-ring reconstructed rainfall variability in Zimbabwe. Climate Dynamics 26:677-685.

Vogel CH (1989) A documentary-derived climatic chronology for South Africa, 1820-1900.

Climatic Change 14:291-307. 
White S (2018) North American climate history (1500-1800). In White S, Pfister C, Mauelshagen F (eds.) The Palgrave Handbook of Climate History. Palgrave Macmillan, London, pp. 297308. 
Table 1. Historical archives and collections used in this study, together with abbreviations for sources used in footnotes in section 3. For further details of these collections, see Nash et al. (2016) for KwaZuluNatal, Nash and Grab (2010) for Lesotho, Nash et al. (2018) for Malawi, and Nash and Endfield (2002) for the southern Kalahari. Lesotho

Council for World Mission (CWM) archive, SOAS, London

Bodleian Library, University of Oxford

Lesotho National Archive, Maseru

Morija Museum and Archives, Morija

KwaZulu-Natal

Bodleian Library, University of Oxford

British Library, London

Council for World Mission archive,

SOAS, London

Evangelisch-lutherisches Missionswerk Niedersachsen, Archiv, Hermannsburg

Houghton Library, Harvard University

Killie Campbell Africana Library, University of KwaZulu-Natal, Durban

Msunduzi Municipal Library,

Pietermaritzburg

National Archives, London

Norwegian Mission Society Archive, Stavanger

\section{Malawi}

National Archives of Malawi, Zomba

Society of Malawi Library, Blantyre

Msunduzi Municipal Library,

Pietermaritzburg

Kew Gardens Archives, London

National Library of Scotland, Edinburgh

University of Aberdeen

University of Glasgow

University of Edinburgh

Bodlean Library, University of Oxford
Name of archive

\section{Key collections and abbreviations in text}

Paris Evangelical Missionary Society (PEMS) and Wesleyan Methodist Missionary Society (WMMS) collections

United Society for the Propagation of the Gospel in Foreign Parts (SPG) collection; Sir Godfrey Lagden diaries

Colonial reports, diaries, incoming/outgoing letters, Blue Books for Basutoland

Leselinyana la Lesotho, Little Light of Basutoland

USPG collection

Various books, British Newspapers 1600-1950 (online), 19th Century British Newspapers (online)

WMMS collection

Hermannsburg Missionary Society (ELM) collection

American Board of Commissioners for Foreign Missions collection

19th century journals and other manuscripts, Natal Witness, Natal Blue Books

Natal Witness, Natal Almanac, Natal Blue Books

British Colonial Office materials, including Natal Blue Books

Norwegian Mission Society (MHS) collection

Manuscript collection; Occasional Paper for Nyasaland; Nyasa News

Manuscript collection; The British Central African Gazette; The Central African Planter; various monographs

Natal Witness newspaper

Various manuscripts

Manuscript collection

Manuscript collection

African Lakes Co Ltd collection

Manuscript collection

Universities' Mission to Central Africa (UMCA)

collection

\section{Southern Kalahari}

CWM archive, SOAS, London

LMS and WMMS collections 
Table 2. Suitability of different documentary source types in relation to the objectives of historical climatology research.

\begin{tabular}{|c|c|c|c|}
\hline Objective & Newspapers & $\begin{array}{l}\text { Missionary (and } \\
\text { other) letters and } \\
\text { reports }\end{array}$ & Diaries and journals \\
\hline $\begin{array}{l}\text { Reconstructing } \\
\text { temporal and spatial } \\
\text { patterns of } \\
\text { weather/climate }\end{array}$ & $\begin{array}{l}\text { Potentially dense and } \\
\text { rich information about } \\
\text { climate variability, } \\
\text { including (dependent } \\
\text { on location) onset/end } \\
\text { of rainy/frost season, } \\
\text { seasonal/annual } \\
\text { rainfall levels, } \\
\text { interannual rainfall } \\
\text { variability, frost } \\
\text { frequency, snow } \\
\text { frequency, snow depth } \\
\text { and duration; some } \\
\text { early instrumental } \\
\text { meteorological data. }\end{array}$ & $\begin{array}{l}\text { Potentially rich } \\
\text { information about } \\
\text { climate variability } \\
\text { (although not } \\
\text { necessarily as dense } \\
\text { as in newspapers), } \\
\text { and with the potential } \\
\text { to reconstruct similar } \\
\text { climate parameters; } \\
\text { rare early instrumental } \\
\text { meteorological data. }\end{array}$ & $\begin{array}{l}\text { If "weather diaries", } \\
\text { then useful for } \\
\text { constructing frequency } \\
\text { counts of binary } \\
\text { meteorological } \\
\text { phenomena, and } \\
\text { start/end dates of } \\
\text { climate events; if } \\
\text { longer format freehand } \\
\text { journals, then similar } \\
\text { potential to letters and } \\
\text { reports; rare early } \\
\text { instrumental } \\
\text { meteorological data. }\end{array}$ \\
\hline $\begin{array}{l}\text { Vulnerability of past } \\
\text { societies and } \\
\text { economies to climate } \\
\text { variations }\end{array}$ & $\begin{array}{l}\text { Likely to include some } \\
\text { details of impacts of } \\
\text { climate variability, but } \\
\text { relatively little on } \\
\text { societal responses to } \\
\text { such variability (unless } \\
\text { at a government level); } \\
\text { suitability will vary } \\
\text { according to the } \\
\text { intended audience of } \\
\text { the newspaper. }\end{array}$ & $\begin{array}{l}\text { Potentially rich } \\
\text { information about the } \\
\text { societal repercussions } \\
\text { of climate variability, } \\
\text { particularly if authors } \\
\text { are situated amongst } \\
\text { rural communities; } \\
\text { suitability may vary } \\
\text { according to focus of } \\
\text { authors (e.g. between } \\
\text { different missionary } \\
\text { societies). }\end{array}$ & $\begin{array}{l}\text { If weather diaries, then } \\
\text { limited usefulness; if } \\
\text { freehand journals, then } \\
\text { similar potential to } \\
\text { letters and reports. }\end{array}$ \\
\hline $\begin{array}{l}\text { Past discourses and } \\
\text { social } \\
\text { representations of } \\
\text { climate }\end{array}$ & $\begin{array}{l}\text { Relatively limited } \\
\text { usefulness, except at a } \\
\text { meta-scale. }\end{array}$ & $\begin{array}{l}\text { Potentially rich } \\
\text { (although not } \\
\text { necessarily dense) } \\
\text { information about past } \\
\text { climate discourses and } \\
\text { social representations } \\
\text { of climate. }\end{array}$ & $\begin{array}{l}\text { If weather diaries, then } \\
\text { limited usefulness } \\
\text { unless the author also } \\
\text { included commentary } \\
\text { on issues such as the } \\
\text { impacts of climate } \\
\text { upon health; if } \\
\text { freehand journals, then } \\
\text { similar potential to } \\
\text { letters and reports. }\end{array}$ \\
\hline
\end{tabular}




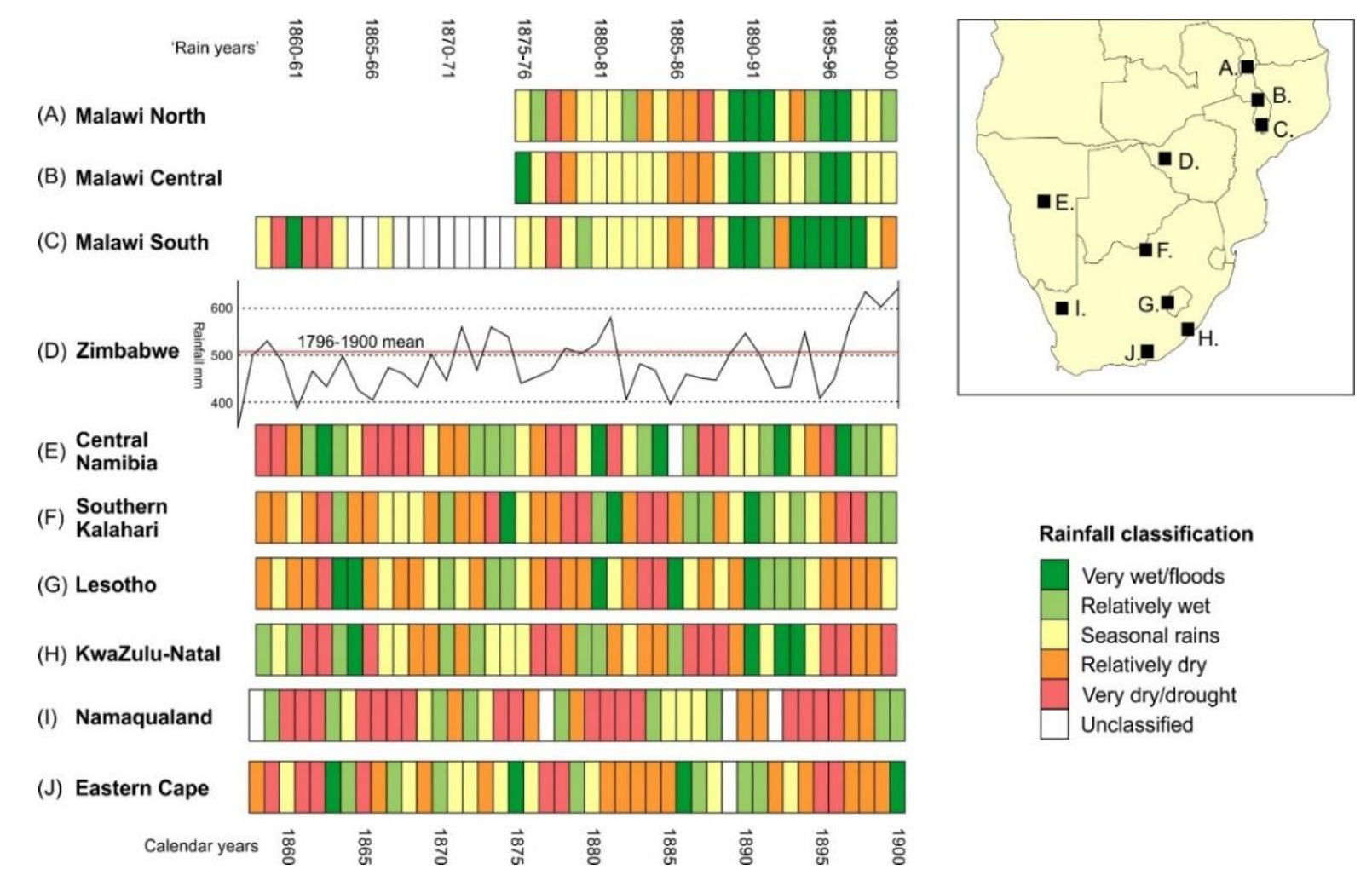

Figure 1. Selected annually-resolved chronologies of mid-late 19th century rainfall variability for the southern African summer rainfall zone. (a)-(c) Documentary-derived series for north, central and southern Malawi (Nash et al., 2018); (d) Tree ring-width series for Zimbabwe reflecting austral summer (November-February) rainfall (Therrell et al., 2006); (e)-(j) Documentary-derived series for central Namibia (Grab and Zumthurm, 2018), the southern Kalahari (Nash and Endfield, 2002, 2008), Lesotho (Nash and Grab, 2010), KwaZulu-Natal (Nash et al., 2016), Namaqualand (Kelso and Vogel, 2007), and Eastern Cape (Vogel, 1989). The multi-year droughts of 1861-63, 1876-79 and 1895-97, which form the focus of this study, are clearly visible in these series. 